\title{
A Falácia Técnico-Garantidora e o Itinerário do Controle: o conselho municipal dos direitos da criança e do adolescente
}

\author{
Jackson da Silva Leal'
}

\section{Resumo}

0 presente trabalho aborda a atuação do Conselho Municipal de Direitos da Criança e do Adolescente, analisando-se as suas procedimentalidades e os contributos para a construção de uma (nova ou não) realidade e imaginário das instituições públicas e da sociedade para com este contingente de indivíduos encerrados nestas categorias infância e juventude. Faz-se uma análise da atuação do Conselho a partir da atenção a quatro elementos específicos: (i) que agentes participam do ConseIho; (ii) formas de atuação; (iii) níveis de participação e (iv) capacidade decisória e interventiva do Conselho, para então poder apresentar algumas reflexões prático-teóricas em que está inserido 0 Conselho, tais como a inclusão no sistema estatal e burocrático. Para o presente trabalho adota-se referencial bibliográfico e documental, partindo-se de um referencial teórico crítico-analítico e reflexivo. Tem como objetivo principal desvelar as complexas e multifacetadas relações em que estão imersas as infâncias e juventudes (várias) no paradigma de gestão humanista e totalitária moderna. Antecipando algumas conclusões, entende-se que o norteador da prática pública estatal para com a juventude tem sido totalitária e incapaz de alterar a dinâmica de sociabilidade perversa em que muitos vivem; camuflada de discursos politicamente corretos, permeado pelo entrecruzamento de interesses privados.

Palavras-chave: Infância e adolescência. Democracia sem fim. Humanismo ocidental. Gestão totalitária.

${ }^{1}$ Graduado em Direito (UCPel); Mestre em Política Social (UCPel) e doutorando em Direito (UFSC); bolsista pesquisador CNPq. jacksonsilvaleal@gmail.com 


\title{
FALLACY GUARANTOR TECHNICAL AND ITINERARY OF CONTROL: The City Council of The Rights of Child
}

\begin{abstract}
This paper investigates the performance of the Municipal Council of Child and Adolescent, analyzing their dynamics and the contributions to the construction of a (new or not) reality and imagination of the public institutions and society to this quota closed individuals in these categories childhood and youth. It is an analysis of council's operations from the attention to four specific elements: (i) agents that participate in the council, (ii) forms of action, (iii) levels of participation, (iv) decision-making capacity and intervention council, so he can present some practical and theoretical considerations that the board is inserted, such as the inclusion in the state system and bureaucratic. For this paper, we adopt bibliographic references and documents, starting from a theoretical critical analytical and reflective. Its main objective is to reveal the complex and multifaceted relationships that are immersed in the childhood and youth (several) in the management paradigm of modern humanistic and totalitarian. Anticipating some conclusions, it is understood that the State publishes a guide of practice for youth has been totalitarian and unable to change the dynamics of social evil in which many live, disguised as politically correct discourses, permeated by the intersection of private interests.
\end{abstract}

Keywords: Childhood and adolescence. Democracy without end. Western humanism. Totalitarian management.

\section{Sumário}

1. Introdução. 2. Da Participação de Direito à Participação de Fato: Análise Conceitual Entre Democracia e Cidadania. 3. Das Categorias Analíticas: Itinerários do Controle/Participação "Democrática". 3.1. Os agentes e o entrecruzamento de interesses privados. 3.2. As formas de atuação e a falácia técnico-jurídico-garantidora. 3.3. Os níveis de participação e a democracia menos que formal. 3.4. A capacidade decisória e interventiva e a cooptação sistêmica. 4. A Infância e Juventude Como Atores/ Sujeitos na Instância de Construção Social. 5. Considerações Finais 


\section{INTRODUÇÃO}

O presente trabalho presta-se a analisar a atuação dos Conselhos Municipais dos Direitos da Criança e do Adolescente (Comdicas), especificamente a partir do caso de Pelotas (RS). Trabalha-se uma reflexão em torno do controle social das políticas públicas e da participação democrática nas políticas sociais, especificamente no que diz respeito aos interesses das crianças e adolescentes.

Neste sentido traz-se algumas categorias para permitir a análise e contribuir com o debate acerca das políticas públicas (ou sociais), sobretudo envolvendo a infância e a adolescência, como também para fortalecer e enriquecer os saberes e discursos acerca do paradigma democrático e de participação cidadã.

Assim, em um primeiro momento analisa-se questões de fundo conceitual e que são de fundamental importância para o desenvolvimento da participação democrática (ou controle social), tais como a concepção de política social e mesmo de espaço público; ou ainda, concepções como democracia e cidadania, que são conceitos intimamente entrelaçados e que dizem respeito diretamente à problemática do controle (participação) de políticas sociais.

Em um segundo momento analisa-se algumas categorias específicas relacionadas ao controle social das políticas públicas, levando-se em conta o paradigma epistemológico em que se encontram. Neste sentido, ainda que em sede introdutório, importa trazer a concepção de modernidade com que se trabalha para efeito desta análise, pois esta definição serve de elemento contextual para outras abordagens.

Assim, entende-se a modernidade e seu paradigma epistemológico a partir do que dispõe Zygmunt Bauman (1998, 2000, 2001, 2005, 2008a, 2008b) quando trabalha a modernidade líquida, quando se possibilitou uma liberdade nunca antes imaginada, ao mesmo tempo em que um pro- 
cesso de fragmentação e isolamento igualmente ímpares na história da humanidade. Contexto este que interfere diretamente na questão da participação democrática e das políticas públicas, que passam a ser reféns e instrumento utilizado/conhecido unicamente na esfera reduzida do que se entende por público nesta modernidade, o espaço do Estado.

Trata-se de uma análise essencialmente bibliográfica e documental e de participações observadoras em reuniões do Comdica-Pelotas.

Trabalha-se a partir de referencial teórico interdisciplinar e propugna-se por rupturas e desvelos das incongruências do paradigma de sociabilidade e da gestão pública, contribuindo para a construção de uma visão desmistificadora do real em que se insere a proposta de irrupção dos sentidos contra-hegemônicos.

\section{DA PARTICIPAÇÃO DE DIREITO À PARTICIPAÇÃO DE FATO: Análise Conceitual Entre Democracia e Cidadania}

Inicialmente, nesta análise teórica, pretende-se tratar de alguns conceitos que têm feito parte das dinâmicas da modernidade e que influenciam diretamente nas concepções e trajetórias das políticas sociais e da participação democrática.

Nesta linha, ressalta-se que se trabalha com uma perspectiva de análise de limites e possibilidades acerca do Conselho Municipal de Direitos da Criança e Adolescente e sua atividade, tratando-se neste espaço do caso do Conselho de Direitos da Criança e do Adolescente de Pelotas (COMDICA-Pelotas/RS).

Não deixando de lado a importância em sua atividade nas modernas democracias ocidentais, como forma de participação e controle das políticas públicas dirigidas à infância e juventude - e esta esfera de reconhecimento e importância que se encontra nas possibilidades, tendo em vista 
o paradigma epistemológico da própria modernidade e suas concepções de liberdade, igualdade, democracia e cidadania, que não permitem dinâmicas e estruturas mais ampliadas de participação.

Assim, objetiva-se um aprofundamento e análise de antinomias conceituais, a fim de contribuir com um possível paradigma de participação mais ampliado, livre e verdadeiramente democrático, para a construção de um paradigma de participação em políticas sociais, virtualizando uma dinâmica de sociabilidade para além da estrutura centralizadora do Estado e também superando a realidade que tem sido dada pelo sistema metaprogramado pelo paradigma positivista burguês.

Com isso, trabalha-se com a concepção de Estado como ente regulador, que subverteu os pilares da emancipação pelos pilares da regulação, como tem proposto Boaventura Sousa Santos $(2000,2006)$ e seus reflexos conceituais e procedimentais.

Nesta linha que se encontra e permite as reflexões permitidas a partir de Zygmunt Bauman (1998), que traz uma análise muito interessante acerca de um imperativo categórico que tem feito parte da modernidade - a obrigatoriedade de ser livre -, e, neste sentido, analisa remontando a Jean Jacques Rousseau:

Seria possivel dizer que o mais considerado, criticado e insultado oráculo de Jean Jacques Rousseau - o de que as pessoas devem ser forçadas a ser livres - tornou-se realidade, depois de séculos, embora não na forma em que tanto os ardentes seguidores como os críticos severos de Rousseau esperavam que fosse implementado (Bauman, 2008b, p. 97).

A partir disso traz-se outro imperativo categórico que se tem forjado e feito cada vez mais intenso na modernidade recente, que é a imperatividade da obrigação/dever de ser democrático, como sendo este o ápice de razão humana ou única forma de ser e estar no mundo moderno; e assim, tal modelo de governo levado a cabo até por meios mais variados 
e não democráticos possíveis e (in)imagináveis, como que simplesmente cumprindo com um mandamento contextual - ocidental humanista - que precisa de justificação. ${ }^{2}$

Neste contexto, trabalha-se com uma concepção de democracia bem além da concepção que se tem trabalhado e proposto mundialmente na modernidade, como mero paradigma de governo; mas sim como um paradigma de democracia fundante, produtora da realidade dos envolvidos e faticamente imbricados no devir histórico da comunidade política.

Tal concepção decorre em grande parte, também, da concepção de cidadania com que se tem trilhado na modernidade, sendo esta mera dinâmica eleitoral, em que a cidadania se tem restringido ao direito de votar como se este ato encerrasse a participação cidadã. Nesta esteira propõe Vera Regina Pereira de Andrade:

[...] o Estado de direito sedimentou um conceito restrito de cidadania porque traz em seu bojo um conceito também restrito de poder, da política e da democracia. Identificado o poder com o poder político estatal, a política é vista como uma prática específica, cujo lugar de manifestação só pode ser o Estado e as instituições estatais e cujo objetivo só pode ser a ocupação do poder estatal (governo/parlamento). Identificada a democracia como uma forma de regime político, a democracia é reduzida à democracia politico-estatal ou à democratização do Estado. E identificada a cidadania com a representação política, é ela reduzida a um epifenômeno da democracia representativa (Andrade, 2003b, p. 69-70).

Tal situação se dá com o progressivo processo de esvaziamento da política e do espaço público, que tão bem tem sido trabalhado por Zygmunt Bauman (1997, 2000), e ainda, as correspondentes concepções de cidadania e democracia, quase que como correlatos de um mesmo processo,

${ }^{2}$ Salientando-se que se fala deste paradigma de democracia representativa menos que formal, característica das nações burguesas e da epistemologia constitucionalista moderna e ocidental! 
que neste processo de confusão acabam por se anular, como apontado pela professora Vera Regina Pereira de Andrade (2003b). Como se propôs anteriormente, este processo da transformação da democracia em forma de governo, do encerramento do potencial emancipatório da participação cidadã, da restrição do espaço da política ao mero espaço público-estatal, é uma arbitrariedade da definição de público e uma castração da concepção de política, como aponta o professor Enrique Dussel (2009) - tais processos não ocorrem de fragmentação e isolamento dos indivíduos que se encerram como em ilhas em si mesmas não ocorrem de forma isolada ou desinteressadamente, mas sim a partir de um intrincado paradigma epistemológico que tem produzido e permitido a modernidade ocidental hegemônica (Santos, 2000, 2006), mantendo seu curso de dominação que se faz essencialmente pelo monopólio do poder-saber e dos espaços restritos da política e da participação.

Este metaprocesso redunda na produção de indivíduos desinteressados ou descrentes, ou ainda por demais ocupados com as questões pessoais, por fazer-se pensar justamente que é pessoal e aleatório. A estes indivíduos em confronto com o cidadão que Bauman (2001) chama de liberdade de jure. Retomando-se a reflexão acerca dos imperativos categóricos da modernidade, do dever ser livre e participar de um regime democrático, sob pena de perder o status de humanitário e civilizado. Ainda Zygmunt Bauman complementa, em resumo ao que se tem trabalhado anteriormente:

Há um grande e crescente abismo entre a condição de indivíduos de jure e suas chances de se tornar indivíduos de facto - isto é, de ganhar controle sobre seus destinos e tomar as decisões que em verdade desejam. É desse abismo que emanam os eflúvios mais venenosos que contaminam as vidas dos indivíduos contemporâneos. Esse abismo não pode ser transposto apenas por esforços individuais: não pelos meios e recursos disponíveis dentro da política-vida auto-determinada. Transpor o abismo é a tarefa da Política com P maiúsculo. Pode-se supor que 
o abismo em questão emergiu e cresceu precisamente por causa do esvaziamento do espaço público, e particularmente da ágora, aquele lugar intermediário, público/privado, onde a política-vida encontra a Política com P maiúsculo, onde os problemas privados são traduzidos para a linguagem das questões públicas e soluções públicas (Bauman, 2001, p. 48-49).

Em complemento a essa ideia dos imperativos categóricos da modernidade (liberdade e democracia - menos que formais), que em regra têm sido acompanhados por mecanismos de neutralização destes próprios postulados, que têm se reestruturado diariamente ao sabor das necessidades do sistema, propõe Zygmunt Bauman "o que a modernidade liberal oferece com uma das mãos ela tende a retirar com a outra. $O$ dever da liberdade, sem os recursos que permitem uma escolha verdadeiramente livre é, para muitos, uma receita para a vida sem dignidade, preenchida, em vez disso, com humilhação e autodepreciação” (Bauman, 1997, p. 243).

Ainda, deste paradigma de democracia e política que, igualmente, decorre a concepção de política social como algo limitado à atuação do Estado, a partir de uma concepção reducionista das potencialidades de participação e construção sociais; e também, como conceito derivativo, o de participação (ou controle) de políticas - que, em especial, interessam para o presente trabalho.

Analisadas algumas proposições de autores que têm se preocupado com o tema do controle (ou participação) social de políticas públicas ou sociais, tais como Alvarez (2004), Calvi (2008), Gohn (2004) e Pochmann (2004), vê-se uma preocupação demasiada com questões procedimentais e de factibilidade, entretanto analisando as preocupações, limites e desafios sobre os quais os autores se debruçam, percebe-se que são questões de fundo conceitual, mais que de procedimentalidade. 
Como se tem trabalhado apresenta-se a situação das políticas sociais e seu controle como uma questão que enfrenta profundo problema conceitual, que não lhe é particular, tendo em vista que tal problema tem se mostrado ser “o” grande problema a ser enfrentado no que diz respeito às questões básicas paradoxalmente problemáticas no paradigma de governabilidade moderna, como democracia, cidadania, participação, público, política.

Neste sentido que se entende estar com razão Boaventura de Sousa Santos, quando entrelaça a política, o Direito e a ciência. Neste caso da política social e o controle social (de políticas) vê-se o quanto as três esferas se permeiam e se complementam. Concorda-se com Boaventura de Sousa Santos (1987, p. 89; 2000, p. 6) quando propugna por uma revolução paradigmática, e propõe a ressignificação da política, do Direito e da ciência, e, por via consequencial, e para efeito deste trabalho, produzirá mudanças paradigmáticas nas dinâmicas e estruturas das políticas sociais e da participação nestas políticas, que se refundam a partir da reconstrução da cidadania, passando de controle de políticas sociais para participação social, tendo em vista a transformação de um paradigma de sociabilidade que vai da regulação para dinâmicas de sociabilidade calcadas na emancipação (Santos, 2009).

Possibilita, assim, a introdução de novos saberes, para além do Estado a da realidade dada e vigente; uma política como concepção alargada de participação e de espaços de diálogo, bem como ainda a retomada do poder de decisão; e, por fim, um direito que se permita pensar para além das estruturas que lhe são dadas como únicas, como ápice da razão humana, ou mesmo o fim da história; mas transformar-se em um Direito que se pretende também construtor da realidade, não mais mero constructo da realidade que lhe cerca e como ferramental de opressão material e simbólica. 
Saliente-se que essa revisão conceitual centra-se no marco de limites do controle/participação em políticas sociais, compreendido o controle de políticas sociais como uma ferramenta importante no marco teórico das políticas sociais vigentes, ou seja, inserido na matriz teórica hegemônica que é incapaz de pensar alternativas ou dinâmicas para além da estrutura estatal contemporânea.

Neste sentido, funciona no interior da dinâmica tecnicista e mecanicista, burocrática weberiana, sendo, portanto, uma ferramenta que grande importância no mundo moderno; entretanto deve-se entender esta como dotada de limites que são mais de cunho teórico do que procedimental, tendo em vista operar a partir dos conceitos (signos e símbolos) predefinidos hegemonicamente, o que lhes impõe uma margem de atuação e tensionamento (ou seja, uma tensão limitada).

No que diz respeito à participação em políticas sociais, esta se encontra no marco das possibilidades, que devem se encontrar sempre abertas para um processo de construção e coprodução; assim, como uma dinâmica de projeção conceitual ou virtualização de uma vida (e seu espaço público ampliado e democrático) que se permite pensar para além dos limites materiais simbólicos e culturais vigentes atrelados à estrutura centralizadora do Estado; pensando-se a partir do que Boaventura Santos aponta como uma revolução paradigmática da política, da ciência e do Direito (Santos, 1987, p. 89).

\section{DAS CATEGORIAS ANALÍTICAS: Itinerários do Controle/Participação "Democrática"}

Desta forma, passa-se à abordagem da categoria de análise e atuação denominada política social e seu derivativo controle ou participação nas políticas sociais, para então avançar na análise da atuação do Conselho de Direitos da Criança e do Adolescente - no caso de Pelotas/RS. 
Entende-se que a concepção de política social tem se associado (ou sido associada) sobretudo à esfera público-estatal, pelos elementos expostos anteriormente, da concepção de política e democracia com que se tem trabalhado na modernidade ocidental hegemônica, e sua restrição de espaços e dinâmicas; assim como o progressivo processo de aumento de controle (em um sentido de regulação e encerramento).

E também a concepção de controle social de políticas públicas, como conceito derivativo de todo este sistema, de igual forma tem sido restringido em seu elemento conceitual, e, sobretudo, em seu elemento procedimental - a esfera de atuação público-restritiva do Estado. Deriva, assim, de um paradigma permeado pela diminuição do espaço público (de todos) e da quase anulação da política (como participação e diálogo em espaços alargados), de um sistema em que a democracia se tornou regime de governo e à cidadania cabe pura e simplesmente resolver quem decide (processo eleitoral), o que a professora Vera Regina Pereira de Andrade chama de epifenômeno da democracia ocidental burguesa (Andrade, 2003b).

Neste contexto, não poderia derivar uma concepção de participação social e políticas sociais que extrapolassem a esfera estatal e interferissem em seu paradigma de regulação, devendo ser um poder regulatório da sociedade perante o Estado, que por sua vez também é regulatório diante da sociedade, ambos se restringindo ao espaço do Estado como atuação política. Tal concepção permeia ainda a análise feita por Maria Lúcia Werneck Vianna (2008) e Lúcia Cortes da Costa (2001).

É nesta linha que se centra a análise do Conselho Municipal de Direitos da Criança e do Adolescente de Pelotas, tendo-se como objetivos principais apresentar os limites e possibilidades desta instituição política e social, ou mais político-sistêmica do que social e participativa em um sentido político efetivo de construção e coprodução de realidades sociais. 
Nesta esteira, de acordo com definição legal proposta pela Lei 8.069/90 (Estatuto da Criança e do Adolescente), no artigo 88, ${ }^{3}$ cabe aos Comdicas a deliberação e controle das políticas sociais, bem como a proposta de programas sociais de atendimento, observadas a formação tripartite e a participação popular (entre outras atribuições regulamentadas por legislações em âmbito estadual e municipal com maiores especificações procedimentais). ${ }^{4}$

Desta feita, a título de análise das possibilidades, analisam-se algumas categorias teóricas e procedimentais com o fim de contribuir com esta atuação, e, sobretudo, com o desvelar da significação desta atuação.

Tem-se claro que, modernamente, na esfera da infância e juventude, a atuação que parte dos órgãos centrais tem se pautado por uma atuação e concepção tradicional/moralista, pseudo-humanista e dominadora, tendo estes indivíduos (a infância e juventude) como meros objetos de intervenção e assujeitamento. Como assevera Alexandre Morais da Rosa,

isto porque a intervenção em adolescentes não pode ser feita assumindo-se uma postura "nefelibata", ou seja, "do povo que anda nas nuvens". Felizes eles - os atores nefelibatas - que continuam aplicando certa

\footnotetext{
${ }^{3}$ Artigo 88. São diretrizes da política de atendimento: I - municipalização do atendimento; II - criação de conselhos municipais, estaduais e nacional dos direitos da criança e do adolescente, órgãos deliberativos e controladores das ações em todos os níveis, assegurada a participação popular paritária por meio de organizações representativas, segundo leis federal, estaduais e municipais; III - criação e manutenção de programas específicos, observada a descentralização político-administrativa; IV - manutenção de fundos nacional, estaduais e municipais vinculados aos respectivos conselhos dos direitos da criança e do adolescente; V - integração operacional de órgãos do Judiciário, Ministério Público, Defensoria, Segurança Pública e Assistência Social, preferencialmente em um mesmo local, para efeito de agilização do atendimento inicial a adolescente a quem se atribua autoria de ato infracional; [...]

${ }^{4}$ No Estado do Rio Grande do Sul aponta-se a Lei n. 9.831/1993 que institui o Conselho Estadual dos Direitos da Criança e do Adolescente (Cededica); e no âmbito do Município de Pelotas/RS a Lei n. 4926/ 2003 que institui o Conselho Municipal de Direito da Criança e do Adolescente (Comdica - Pelotas).
} 
parcela do poder estatal em face dos adolescentes objetificando-os sem que se dêem conta de que esta intervenção produz, necessariamente, vítimas (Rosa, 2007, p. 1).

Com este objetivo de tentar contribuir com a concepção e atuação do Conselho, mas, sobretudo, entender a analisar a sua atuação é que se instrumentaliza a pesquisa a partir da resposta de alguns elementos (ferramentas analítico-conceituais), quais sejam:

(a) o entrecruzamento de agentes e interesses privados, que diz respeito à comercialização de humanidade no que diz respeito à seara da atuação público-estatal em relação à infância e juventude; (b) as formas de atuação e a falácia técnico-jurídico-garantidora, que se dirige às dinâmicas que se pautam meramente pela consecução de dispositivos legais, como se a letra fria da lei tivesse o condão de alterar a vida das pessoas e seus reais sofrimentos, acreditando na falácia das garantias legais e fundamentais, em uma verdadeira ficção jurídico-política e social; (c) os níveis de participação e a democracia menos que formal, em que se analisa a composição do Conselho e sua dinâmica deliberativa e representativa, onde, a exemplo das estruturas superiores de governo, a democracia não passa de uma denominação e uma capa legitimante, não havendo uma verdadeira e real participação dos realmente interessados nas decisões que são tomadas; (d) a capacidade decisória e interventiva, na qual se debruça a análise nas questões de cunho prático em relação às atividades do Conselho e a capacidade real de mudar a vidas das pessoas, as potencialidades e o meio sistêmico em que se encontra e que inviabiliza as potencialidades reais de alteração.

Categorias analíticas que se passa a analisar em detalhes, a fim de contribuir com uma tentativa de desvelar e adensar a discussão e reflexão em torno dos Conselhos, e mais especificamente do Conselho de Direitos 
da Criança e do Adolescente no caso de Pelotas, ${ }^{5}$ como ferramenta de controle ou participação em políticas publicas? Ou ainda, como uma estrutura autônoma que contribui com um processo para a emancipação social; ou, mais uma ferramenta inserida no sistema público estatal e cooptado por dinâmicas totalitárias de gestão?

Salientando que se parte da contribuição de Enrique Dussel (2007, 2009), quando propõe uma principiologia emancipatória para a atuação política insurgente e transformadora, que se estrutura a partir de um trinômio composto por: (i) princípio político de legitimidade democrática; (ii) princípio ético material; e, (iii) princípio da factibilidade ética. Ou ainda, quando analisa o conceito de política a partir de três instâncias conceituais e analíticas distintas que dizem respeito e se entrelaçam diretamente com estes princípios; assim, entende-se a política a partir das esferas: (a) dos princípios implícitos e como projeção ideológica; (b) a estrutura das instituições políticas; e por último, (c) a práxis e atuação política. Assim, passa-se à análise das categorias, sob a luz destes princípios que serão mais bem apresentados juntamente com a análise das categorias.

\subsection{Os Agentes e o Entrecruzamento de Interesses Privados}

No que diz respeito a esta primeira categoria de análise, refere-se mais especificamente aos agentes e os interesses que se cruzam no seio da atuação do Conselho de Direitos da Criança e do Adolescente. Em resumo, a Lei que 8.069/90 (ECA) institui a necessidade da existência dos Conselhos (Comdicas - municipais; e Cedicas - estaduais), e em parte regulamenta, ou pelo menos direciona, a gestão destes Conselhos, em

${ }^{5}$ Muito embora tal estrutura, e, portanto, tal analise possa ser trasladada para vários outros conselhos de direitos, tanto em nível municipal, quanto estadual, que seguem diretrizes legais e procedimentais muito semelhantes. 
seu artigo $88^{6}$ define um elemento essencial para essa primeira categoria analítica; que é a composição paritária entre governo, as entidades assistenciais $^{7}$ e o terceiro setor ${ }^{8}$ a partir da diretriz de deliberação e controle acerca das políticas públicas como institui a Lei (municipal) 4.926/2003 em seu artigo $10^{\circ},{ }^{9}$ no caso de Pelotas/RS.

Como se constata, a formação do Conselho de Direitos da Criança e do Adolescente no município de Pelotas, no Estado do Rio Grande do Sul, tem sua formação definida em seu artigo $10^{\circ}$, e ainda, com vinculação ao poder Executivo e prescrições específicas acerca da forma de indicação do Executivo para ocupação de suas vagas no Conselho no artigo $11 .{ }^{10}$ Essa

${ }^{6}$ Artigo 88. São diretrizes da política de atendimento: I - municipalização do atendimento; II - criação de conselhos municipais, estaduais e nacional dos direitos da criança e do adolescente, órgãos deliberativos e controladores das ações em todos os niveis, assegurada a participação popular paritária por meio de organizações representativas, segundo leis federal, estaduais e municipais; III - criação e manutenção de programas específicos, observada a descentralização político-administrativa; IV - manutenção de fundos nacional, estaduais e municipais vinculados aos respectivos conselhos dos direitos da criança e do adolescente; [...] (grifo do autor).

${ }^{7}$ Instituições assistenciais são conformadas, em geral, por Organizações Não Governamentais (ONGs) que prestam serviço público de atendimento e assistência, prestação essa que é remunerada pelo Estado, e, portanto, com certo caráter empresarial-assistencial.

${ }^{8}$ Instituições do terceiro setor são as que, se presume, possam contribuir com a atividade dos Conselhos, tais como representantes de universidades, de instituições representativas, tais como a Ordem dos Advogados do Brasil (OAB), Conselho Regional de Psicologia [...].

${ }^{9}$ Artigo $10^{\circ}$ - O Conselho Municipal dos Direitos da Criança e do Adolescente, órgão normativo, deliberativo e controlador da política de atendimento, vinculado administrativamente à Secretaria Municipal de Governo, será regulamentado pela presente Lei.

${ }^{10}$ Artigo 11 - O Conselho Municipal dos Direitos da Criança e do Adolescente terá composição tripartite, assim constituída: I - um terço de representantes do poder público municipal, com a representação dos seguintes órgãos: a) Secretaria Municipal dos Direitos Humanos, Cidadania e Assistência Social; b) Secretaria Municipal da Educação; c) Secretaria Municipal da Cultura; d) Secretaria Municipal da Saúde; e) Secretaria Municipal de Governo; f) Secretaria Municipal de Qualidade Ambiental; g) Câmara Municipal de Pelotas. II um terço de representantes de entidades não governamentais que prestem serviço direto e sistemático às crianças e adolescentes através de programas de proteção e socioeducativos, constante no artigo $5^{\circ}$ desta Lei; III - um terço de representantes de outras organizações que desenvolvem outras formas de prestação de serviços, inseridas nas políticas sociais constantes no artigo $2^{\circ}$ desta Lei. $\S 1^{\circ}-$ As representações constantes nos incisos II e III serão estipuladas pelo Regimento Interno do Conselho Municipal dos Direitos da Criança 
é a responsável por propor, fiscalizar e controlar o Estado, e representar os interesses dos atendidos (em tese) - as crianças e os adolescentes, de acordo com o paradigma de garantias proposto na Constituição Federal de 1988 e seu Estado Democrático de anti-Direito e Consumo.

Entende-se que a dinâmica do Conselho (e não apenas os Condicas, mas também os demais Conselhos de Direitos em nível Estadual e Federal) na modernidade recente se propõem como sendo o ápice da razão representacional, instrumental e técnico-formal, ou mesmo como o fim da história em termos de sociabilidade, mas que nada mais são que a mercadorização da sociabilidade humana e sua capacidade de interferir no paradigma estável e inseguro do capital.

Tal apontamento, ou afirmação, reporta-se ao fato de a modernidade, ou o sistema que assegura a modernidade hegemônica em marcha, mudando, alterando-se de forma camaleônica para se manter da mesma maneira, ou seja, perpetuando suas bases estruturais intactas; não cometendo o mesmo erro que a modernidade pesada de viés fordista (Bauman, 1998), atrela-se o mercado dos serviços, e, sobretudo, inclui-se como sendo um dos grandes clientes e fornecedor de demanda consumidora, o maior guardião de serviços prestados (e consumidos) - o Estado - e todo seu insuficiente aparato institucional e simbólico de garantias, com as quais não pode arcar sozinho, tendo que passar adiante ou partilhar esses serviços e demandas consumidoras.

e do Adolescente, garantida a paridade prevista no artigo 88, inciso II, da Lei Federal $\mathrm{n}^{\mathrm{o}}$ 8.069/90, sendo que as do inciso II deverão ser previamente escolhidas pelo Fórum Municipal dos Direitos da Criança e do Adolescente. $\S 2^{o}-$ Os conselheiros representantes do poder Executivo serão indicados pelo prefeito municipal, dentre pessoas de sua confiança e com poderes de decisão no âmbito de sua competência. $\S 3^{\circ}-\mathrm{O}$ conselheiro representante do poder Legislativo será indicado pelo presidente da Câmara Municipal de Vereadores. $\S 4^{\underline{0}}$ - As entidades não governamentais serão eleitas pelo Fórum Municipal dos Direitos da Criança e do Adolescente, nos termos dos artigos $8^{\circ}$ e 11 desta Lei. $\S 5^{\circ}-$ Cada órgão público e entidade civil deverá indicar o membro representante no Conselho, bem como o respectivo suplente. 
Assim, vê-se que a estrutura dos Conselhos, e na qual estes estão inseridos é permeada de interesses privados, privatistas, que fogem ao interesse dos reais interessados, e principalmente afetados pelas decisões que são tomadas no seio desta atuação, e, sobretudo, acentua-se a incapacidade de realmente fiscalizar e tornar-se um empecilho para esta máquina que se retroalimenta. Nesta linha aponta István Mészáros:

O capital é um modo de controle que se sobrepõe a tudo o mais, antes mesmo de ser controlado - num sentido apenas artificial - pelos capitalistas privados [...] as perigosas ilusões de que se pode superar ou subjugar o poder do capital pela expropriação legal/política dos capitalistas privados surgem quando se deixa de levar em conta a natureza real do relacionamento entre controlador e controlado. Como um modo de controle sociometabólico, o capital, por necessidade, sempre retém seu primado sobre o pessoal por meio do qual seu corpo jurídico pode se manifestar de formas diferentes nos diferentes momentos da história. [...] até mesmo a substituição completa do pessoal burocrático deixaria de pé o edifício do sistema do capital pós-capitalista, exatamente como a invenção do capitalista solícito, se fosse viável de alguma forma milagrosa não iria alterar minimamente o caráter absolutamente desumanizante do sistema do capital capitalista avançado (Mészáros, 2011, p. 98).

A partir disso, visualiza-se tal paradigma de gestão como sendo sistemicamente incapaz de exercer as funções para as quais, falaciosamente, fora criado, quais sejam: (i) propor políticas eficazes em relação às reais (e drásticas) condições em que se encontram a infância e juventude, sendo, portanto, uma função de intervenção e modificação da realidade que está fadada ao fracasso, tendo em vista que serve mais como um elemento de legitimação do Estado e do próprio mercado de Direito e suas garantias técnico-mecanicistas e que partem do próprio Império, e, portanto, opera a partir de suas dinâmicas e matriz teórica. E a segunda (ii) controlar, que está impedida, tendo em vista que é mais um elemento controlado do que propriamente controlador, justamente por estar e depender do sistema 
para seu funcionamento e manutenção; estando umbilicalmente sendo alimentado e alimentando o próprio sistema e sua necessidade de estratégias legitimadoras e justificadoras do Estado Democrático, como meros imperativos categóricos. Nesta linha aponta István Mészáros:

A razão principal por que este sistema forçosamente escapa a um significativo grau de controle humano é precisamente o fato de ter, ele próprio, surgido no curso da história como uma poderosa - na verdade, até o presente, de longe a mais poderosa - estrutura totalizadora de controle à qual tudo o mais, inclusive seres humanos, deve se ajustar, e assim provar sua viabilidade produtiva, ou perecer, caso não consiga se adaptar. Não se pode imaginar um sistema de controle mais inexoravelmente absorvente - e, neste importante sentido, totalitário - do que o sistema do capital globalmente dominante, que sujeita cegamente aos mesmos imperativos a questão da saúde e a do comércio, a educação e a agricultura, a arte e a indústria manufatureira, que implacavelmente sobrepõe a tudo seus próprios critérios de viabilidade, desde as menores utilidades de seu microcosmo até as mais gigantescas empresas transnacionais, desde as mais íntimas relações pessoais até aos mais complexos processos de tomada de decisão dos vastos monopólios industriais, sempre a favor dos fortes e contra os fracos $(2011$, p. 96).

Neste contexto, em que István Mészáros (2011) aponta como sendo irônico ou mesmo inconcebível se falar em democracia, tendo em vista estar este paradigma de gestão, incluindo a estrutura estatal, mergulhada no paradigma do Império (Hardt; Negri, 2006) do capital, e, portanto, submetido a suas dinâmicas de procedimentalidade, cujas estratégias garantidoras se apresentam meramente como elementos legitimadores do próprio sistema.

Sendo assim, destituídos do primeiro princípio fundamental preconizado por Enrique Dussel (2007, 2009), que é o fundamento político democrático, tendo em vista que os afetados estão apartados de tais dinâ- 
micas de poder e capital (predominantemente simbólico, mas também material), o que, por sua vez, subtrai o fundamento ético desta projeção política ideológica de manutenção sistêmica.

\subsection{As Formas de Atuação e a Falácia Técnico-Jurídico-Garantidora}

Esta segunda categoria que trata das formas de atuação e a falácia técnico-jurídico-garantidora é a ferramenta analítica com a qual se ocupa a lente crítica deste trabalho.

Neste sentido, verifica-se a dependência do Conselho como instituição social ante o sistema e o Estado desde a sua gênese conceitual (na forma como havia sido pensado no Brasil e nas modernas democracias representativas menos que formais); na sua instituição, como definido na própria legislação fundacional em seu artigo $10^{\circ}$ supramencionado (lei 4.926/2003 ${ }^{11}$ - no caso de Pelotas); ou ainda, quando depende financeiramente de um Fundo instituído no artigo 88 (inciso IV - suprarreferido) regulamentado pela lei municipal instituidora e regulamentadora do Conselho, como no caso de Pelotas/RS em seus artigos 21 e 23 (da lei $4.926 / 2003)^{12}$ que destina ao chefe do poder Executivo, mediante decreto,

\footnotetext{
${ }^{11}$ Essa realidade de dependência dos Conselhos ante o poder público estatal estende-se às demais realidades municipais.

${ }^{12}$ Artigo 21 - Fica criado o Fundo Municipal dos Direitos da Criança e do Adolescente, instrumento de captação e aplicação dos recursos dos Direitos da Criança e do Adolescente. Parágrafo Único - O Fundo Municipal dos Direitos da Criança e do Adolescente será regulamentado por Decreto do Prefeito Municipal. Artigo 22 - Constitui receita do Fundo Municipal dos Direitos da Criança e do Adolescente: I) recursos orçamentários destinados pelo Município, pelo Estado e pela União; II) recursos oriundos de convênios atinentes a políticas para o atendimento de crianças e adolescentes firmados pelo Município; III) doações; IV) multas previstas na Lei Federal no 8.069/90; V) outras que venham a ser instituídas. Artigo 23 - A gestão do Fundo Municipal dos Direitos da Criança e do Adolescente é de responsabilidade da Secretaria Municipal de Direitos Humanos, Cidadania e Assistência Social, sendo gerenciado por um Administrador, devidamente indicado pelo respectivo Secretário (grifo do autor);
} 
a regulamentação do Fundo, bem como vincula sua gestão à Secretaria Municipal de Direitos Humanos, demonstrando-se claramente a submissão a esta esfera que deveria ser inicialmente política e participativa, mas é transformada em mais uma repartição (ou esfera) pública-restritamente estatal que fica subjugada às bandeiras partidárias; e, por fim, a submissão à margem de atuação discricionária do poder público municipal na figura do poder Executivo que pode indicar nomes para ocupar postos no Conselho, bem como a necessidades de aprovação do poder Legislativo relativo aos orçamentos (...), o que demonstra ser mais um órgão controlado do que controlador, emperrado na burocracia sistemicamente paralisante e mantenedora da ordem vigente burguesa.

Assim, acerca das formas de atuação dos conselhos e sua procedimentalidade pautada por estruturas hegemonicamente definidas e controladas pode-se afirmar que meramente virtualizam a consecução de dispositivos legais que se reduzem à letra morta plasmada em um documento que aceita qualquer conteúdo ainda que desprovido de intencionalidade ética ou dinamização efetiva.

Nesta esteira, entende-se que a estruturação, e, sobretudo, a dinamização da atuação dos Conselhos têm se orientado por um paradigma de gestão do Império (Hardt; Negri, 2006) burguês e sua estrutura material e simbólica positivista, mecanicista newtoniana e burocrática weberiana; legitimando-se a partir do discurso das garantias e da segurança jurídica, bem como da bendita supremacia constitucional e da soberania estatal clássicos e atuais elementos discursivos legitimadores do constitucionalismo liberal burguês. Nesta mesma linha, Niklas Luhmann aponta, acerca da procedimentalidade do sistema que se utiliza de redutores de complexidade para produzir e legitimar o rechaço ante as demandas sociais e populares: 
O sistema não tem capacidade de apresentar uma variedade suficiente para responder, ponto por ponto, à imensa possibilidade de estímulos provenientes do meio. Assim, o sistema requer o desenvolvimento de uma disposição especial para a complexidade, no sentido de ignorar, rechaçar, criar indiferenças, enclausurar-se em si mesmo. Por isso, surgiu a expressão redução de complexidade, no que se refere à relação do sistema com o meio, mas também consigo mesmo, principalmente quando se tratava de compreender as instâncias de racionalidade, as agencias de planejamento localizadas dentro do próprio sistema (Luhmann, 2010, p. 179).

O que por sua vez redunda em uma prática que, na própria matriz teórica e fundamento de ser, forja as construções factuais e simbólicas para a sua premeditada incapacidade de transformar e irritar o sistema. Como propõe Enrique Dussel, “el efecto contrario sería el gobierno de los expertos, pretendidamente neutrales, que piensan refutar la legitimidad democrática con la eficacia tecnológica de la pura gobernabilidad” (2009, p. 425).

Assim está estruturado o contexto que se justifica (ou é explicado) como sendo emperrado por uma suposta burocracia que não funciona, ou mesmo por uma cultura marcada pela corruptibilidade humana, ou ainda por uma suposta impossibilidade econômico-material. Como apresenta Enrique Dussel $(2007,2009)$ a partir de sua principiologia emancipatória e insurgente para a política, estariam os Conselhos desprovidos de fundamento ético, pois em sua própria fundação já são destituídos de suas reais intencionalidades e fadados ao fracasso procedimental; e assim, desprovidos de factibilidade política, tendo em vista que utilizados como meros sucedâneos políticos legitimadores e aparentes.

\subsection{Os Níveis de Participação e a Democracia Menos que Formal}

Nas linhas em que vem sendo exposta a questão é que se permite entender como problemática a situação e paradigma teórico e prático em que se inserem os Conselhos, em especial o caso de Pelotas/RS; no sim- 
ples sentido de que tal dinâmica tem sido dada como sendo um processo pronto e acabado, tendo-se tornado os Conselhos e mecanismos semelhantes criados no interior do sistema como dogmas infalíveis do controle da gestão e do capital na sua construção material e simbólica.

É nesta linha que se aborda a terceira categoria de análise, que são os níveis de participação e a democracia menos que formal. Tendo em vista que, como já se destacou, a conformação se dá por um processo de privatização e representação de interesses privados e empresariais, não se configurando uma participação efetiva dos reais atingidos e principais interessados nas resoluções e decisões do Conselho.

Dessa forma, aponta Enrique Dussel acerca desta imperiosa necessidade de legitimidade material (e não puramente formal e pseudodemocrático e representativo):

la comunidad política, entonces, como comunidad de comunicación publica desde una estructura del poder que queda delimitada en un campo político, tiene siempre implícita una referencia ultima al criterio político de legitimidad de todas las normas legales, acciones o instituciones que determine. Este criterio ultimo de legitimidad política es siempre y de alguna manera el de la participación simétrica de los afectados (afectados por lo que ha de resolverse), teniendo como instrumento fundamental para alcanzar los acuerdos algún tipo de instituciones donde se expresan argumentos, razones (que pueden también ser narrativas simbólicas o míticas en su origen), todo lo cual está motivado por cierto tipo de igualdad política, que permite la homogeneidad e la voluntad general (Dussel, 2009, p. 397).

A partir disso fala-se em incapacidade de dar conta de pressupostos básicos conceituais, tais como o princípio da legitimidade democrática, preconizado por Enrique Dussel (2009), e também demonstrando o teor e vinculação sistêmica e estrutural da gestão dos Conselhos; deturpando e desvirtuando (ou neutralizando) as potencialidades legitimadoras da instituição de caráter político e participativo. Ainda para Enrique Dussel: 
Este principio está vigente desde el momento en que la comunidad decide institucionalizarse originariamente (antes aún de la Constitución), y debe ser cumplido en todos los momentos del despliegue de todos los procesos políticos sin excepción alguna. El centralismo democrático (un círculo cuadrado contradictorio), la gobernabilidad de la democracia del Imperio, o el lograr gobernar siendo minoría (engañando a las mayorías con legitimidades aparentes como la weberiana o liberal), deben ser rechazadas y superadas por una atención continua en el cumplimiento perenne de este principio normativo. En lo oscurito (lo no-público), de la elite en el poder burgués, del Departamento de Estado o del Comité Central, nunca podrán alcanzarse acuerdos legítimos, democráticos. Es la enseñanza mayor dejada del descalabro del socialismo real (2006, p. 56-57).

No que diz respeito aos níveis de participação, este paradigma que se tem desenvolvido e proposto para os Conselhos se apresenta como sendo mais uma demonstração da prodigalidade desta dinâmica de gestão hegemônica; que transforma a política e sua imanência dialética, deliberativa, construtiva e interventiva, e sua potencialidade humana e emancipatória em dinâmicas técnicas e mecânicas estéreis; além de inserir tais constructos sociais na estrutura centralizadora do Estado e sua burocracia weberiana, a partir de estratégias discursivas e legitimantes que descartam saberes, experiências e procedimentos inapropriados que não se coadunam com a agenda científica de gestão atuarial. Assim aponta Enrique Dussel,

el pueblo establece una frontera o fractura interna en la comunidad política. Pueden haber ciudadanos miembros de un Estado, pero del bloque en el poder que se distingue del pueblo como los insatisfechos en sus necesidades por opresión o exclusión. Llamaremos plebs (en latín) al pueblo como opuesto a las elites, a las oligarquías, a las clases dirigentes de un sistema político. Esa plebs, una parte de la comunidad, tiende sin embargo a englobar a todos los ciudadanos (populus) en un 
nuevo orden futuro donde las actuales reivindicaciones serán satisfechas y se alcanzarán una igualdad gracias a una lucha solidaria por los excluidos (2006. p. 64-65).

Nesta linha, a partir de estratégias de administração material e simbólica orientada por (pseudo)garantias, como sendo constructos prontos e acabados; como resultado do fim da História e que não se permite pensar ou virtualizar nada além do deserto do real que constroem ao mesmo tempo em que projetam como sendo a única alternativa; ou contra a qual não há alternativa - tornando-se este o principal lema ou dogma da modernidade de orientação thatcheriana. ${ }^{13}$

\subsection{A Capacidade Decisória e Interventiva e a Cooptação Sistêmica}

No que diz respeito à última categoria que fundamenta esta abordagem, esta diz respeito à capacidade decisória e interventiva do Conselho em meio a uma estrutura sistêmica e hegemonicamente orientada.

De acordo com a legislação que regulamenta o Conselho em âmbito local (municipal - adotando-se o caso do município de Pelotas/ $\mathrm{RS})$, em seu artigo $1^{\mathrm{o} 14}$ define que a política de atendimento à criança e ao adolescente em plano municipal (local) é feita mediante o estabelecimento de normas gerais. Ainda em seu artigo $10^{\circ}$ supracitado define como sendo um Conselho de Direitos, e, portanto, deliberativo, fiscalizador e propositivo.

\footnotetext{
${ }^{13}$ Remetendo à profecia de Margaret Thatcher quanto à inevitabilidade do desenvolvimento e à modernidade burguesa.

${ }^{14}$ Artigo $1^{o}$ - Esta Lei dispõe sobre a política municipal de atendimento dos direitos da criança e do adolescente e estabelece normas gerais para sua adequada aplicação.
} 
Nesta linha, aponta-se uma incongruência técnico-legal que desnuda a falácia da dinâmica de garantias proposta pela modernidade liberal, incongruência esta que se dá no momento em que a Constituição Federal de 1988, em seu artigo $227,{ }^{15}$ aponta os direitos e garantias específicas da criança e do adolescente; deixando lacunosa a regulamentação de tais garantias que não se realizam por mágica; o que ficaria, assim, a cargo de legislação infraconstitucional específica definindo políticas efetivas.

Posteriormente surge então a Lei 8.069/90 (ECA) regulamentando e agrupando os temas vinculados à questão da infância e juventude, com exceção de alguns temas pontuais, tais como, o caso dos Conselhos, acerca dos quais o ECA apenas enuncia a criação, delegando tal desiderato para momento $a$ posteriori e com legislação específica de instituição nas três esferas de atendimento, o que se dá no Estado do Rio Grande do Sul com a Lei n⿳⺈ 9.831/1993 e no âmbito do município de Pelotas/RS, como já referido, apenas no ano de 2003.

A legislação estadual em seu artigo $1^{016}$ define o Conselho em âmbito regional como sendo um órgão deliberativo, propositivo e controlador de políticas públicas, com redação muito próxima da proposta no próprio ECA de âmbito nacional e também na legislação municipal, deixando claro que se trata de uma inintencionalidade política ou mesmo sistêmica. Utilizando-se de estratégias retóricas, legais e técnico-mecanicistas que

\footnotetext{
${ }^{15}$ Artigo 227 - É dever da família, da sociedade e do Estado assegurar à criança e ao adolescente, com absoluta prioridade, o direito à vida, à saúde, à alimentação, à educação, ao lazer, à profissionalização, à cultura, à dignidade, ao respeito, à liberdade e à convivência familiar e comunitária, além de colocá-los a salvo de toda forma de negligência, discriminação, exploração, violência, crueldade e opressão. [...]

${ }^{16}$ Artigo $1^{0}$ - O Conselho Estadual dos Direitos da Criança e do Adolescente - Cedica, instituído pelo parágrafo $2^{\circ}$ do artigo 260 da Constituição do Estado, é órgão público normativo, deliberativo e controlador das políticas e das ações estaduais voltadas para a infância e a juventude.
} 
atribuem e repartem (confundem) competências para manter a situação da juventude e da infância apenas no plano legal e morto da letra da Constituição Federal defendida como cidadã e democrática.

Ademais, a própria Constituição Federal em seu artigo $24^{17}$ define como sendo de competência concorrente entre a União, o Estado e o município a matéria referente à proteção da infância e adolescente e que, em se tratando de competência concorrente, cabendo à União definir normas gerais, ao Estado normas de âmbito regional e ao município a regulamentação pormenorizada do âmbito local de aplicação, demonstrando-se de forma cabal o quanto é ilegítima em termos de estruturação e falho na aplicação que lhe tem sido dada ou outorgada. Como analisa Niklas Luhmann, "o funcionalismo estrutural se aliou, assim, em muitos casos, à planificação de cima, ao controle, e o conceito de sistema se converteu em um instrumento de racionalização e reforço das estruturas de domínio” (2010, p. 39).

Neste sentido que se entende estar o Conselho de Direitos da Criança e do Adolescente imerso em um sistema fechado e permeado por discursos que mantêm ou preconizam unicamente o imperativo categórico da democracia liberal e produzem muito menos que isso no plano da materialidade; utilizando-se de discursos já apontados antes, como a emperrada burocracia weberiana proposta pelo próprio paradigma de gestão, e na incapacidade material que a própria matriz teórica do Império define hegemonicamente. Assim propõe Niklas Luhmann:

Fala-se exclusivamente em racionalidade do sistema. Se o sistema opera a diferença com o meio, mediante um encerramento operativo, então, o sistema desenvolve uma capacidade de indiferença frente ao

\footnotetext{
${ }^{17}$ Artigo 24. Compete à União, aos Estados e ao Distrito Federal legislar concorrentemente sobre: [...] XV - proteção à infância e à juventude; [...] § $1^{\circ}$ - No âmbito da legislação concorrente, a competência da União limitar-se-á a estabelecer normas gerais. $\S 2^{\underline{0}}-$ A competência da União para legislar sobre normas gerais não exclui a competência suplementar dos Estados. $\S 3^{0}$ - Inexistindo lei federal sobre normas gerais, os Estados exercerão a competência legislativa plena, para atender a suas peculiaridades. $\S 4^{\circ}-$ A superveniência de lei federal sobre normas gerais suspende a eficácia da lei estadual, no que lhe for contrário.
} 
meio. Racionalidade do sistema significaria, assim, a possibilidade de tornar reversível que aspectos do meio possam ser levados em conta pelo sistema, mediante um aumento da capacidade de irritabilidade e de ressonância que se reforça no sistema. Portanto, trata-se de um paradoxo utópico, que oscila entre a exclusão do meio e a reentrada de aspectos do meio, mediante inclusão no sistema (2010, p. 199).

Demonstra-se que não existe qualquer compromisso com a construção participativa da sociedade, nem com uma intencionalidade de efetiva representação e construção (modificação) das condições de vida das categorias implicadas nas problemáticas sociais; estando desprovido de factibilidade ética e política ou mesmo de uma práxis político-social como propõe Enrique Dussel (2007, 2009), verifica-se apenas mais um mecanismo que serve de legitimação do imperativo categórico que é a democracia moderna menos que formal.

Nesta linha acredita-se ter apresentado ao menos uma reflexão e instigação em torno das limitações teóricas e práticas que cercam a problemática moderna dos Conselhos, utilizando-se o caso do Conselho de Direitos da Criança e do Adolescente de Pelotas; tendo-se claro nesta abordagem a incapacidade (e inintencionalidade) de esgotar a complexa estrutura e dinâmica dos Conselhos de Direitos da Criança e do Adolescente; tendo em vista a multifatorialidade com que trabalham em termos de estrutura pública e política; os interesses das categorias que congrega (infância e juventude) e também a imensa pluralidade de significações que permeiam estas análises e reflexões.

\section{A INFÂNCIA E JUVENTUDE COMO ATORES/SUJEITOS NA INSTÂNCIA DE CONSTRUÇÃO SOCIAL}

Após analisar as relações da juventude com a estrutura políticojurídica dos Conselhos em sua complexa problemática que vai desde os discursos humanistas ocidentais até as práticas de total desrespeito pela 
identidade e pela corporalidade dos indivíduos que compõem a categoria juventude, e que apenas tem sido objeto de intervenção, dominação e docilização mente-corpo, ainda que sob uma capa humanitária e filantrópica, passa-se a uma análise na qual se propugna por um paradigma jurídicopolítico alternativo e uma consequente e nova dinâmica de sociabilidade.

Entende-se a juventude como categoria, e, sobretudo, como grupo que guarda a potencialidade de contribuir decisivamente para o processo de (re)politização social a partir de um novo marco de alteridade e reconhecimento de diferenças, calcados no diálogo e nas trocas democráticas. Alessandro Baratta permite a análise da infância e como categoria uma, ${ }^{18}$ classe ou grupo de interesse, ainda que multifacetada e imensamente heterogênea, mas unificados na condição de subalternidade; constituindo-se, como afirma Baratta (2007) em uma nação (de corpos e identidades) a ser inserida na dinâmica e concepção nova de cidadania para a conformação de um estado Mestiço de cidadanias plurais da democracia instituída pela cidadania instituinte. Nesta linha escreve Alessandro Baratta (2007, p. 13):

No soy yo quien ha inventado esta hermosa metáfora: los niños como una de las patrias que concurren a formar el Estado mestizo. La niñez como ciudadanía representa un momento propulsor y una fuente de verdad de los que se alimenta el proyecto de la alianza, la refundación del conjunto de las instituciones públicas según el modelo democrático que me he permitido presentar aquí. [...]El Estado mestizo es el Estado que se alimenta también, y sobre todo, de esta ciudad de los niños, una ciudad que es una enorme metrópolis que casi llega a ser tan grande como la mitad de la humanidad. No podemos perder la riqueza potencial contenida en este proceso de refundación del Estado: están en juego no sólo los derechos de los niños, está en juego la existencia de la propia humanidad.

${ }^{18}$...entende-se que o autor englobou em tal proposta a juventude - que interessa para efeito deste trabalho. 
A juventude construída a partir desta liminaridade e permeada desde a sua gênese por sentimentos antagônicos e ambivalentes, constituindo uma relação paradoxal, tendo em vista que foi construída como grupo ou categoria a partir da modernidade recente, como forma de conceituação de um grupo e delimitação de espaço-tempo em que estes indivíduos integrantes seriam formados para a idade adulta capitalista $\mathrm{e}$ burguesa, recebendo a lapidação da formação que se inicia desde a tenra infância.

Nesta linha, a juventude se constitui a partir de forte dinâmica de vigília adulta e societal, que lhe imprime uma dinâmica altamente moralizante e repressiva, a fim de produzir corpos dóceis e afeitos ao trabalho, à produção e à vida proba que preconiza a modernidade e o ethos burguês.

Com isso, a juventude, diante deste poder altamente repressor e tutelador, a juventude se constitui como o outro da adulteridade, como que em uma relação de espelhos, como proposto por Santos (2006). Dito isto, a juventude tem como característica alguns elementos como a intensidade de relações e emoções, aptidões noturnas desejantes e carnais, irritabilidade/irresignação intensas [...] e ainda, uma profunda ansiedade enquanto aguardam e anseiam pela vida adulta.

Sentimento de ansiedade ainda, que pode ser causado, em grande medida, pelo processo de repressão e castração com que a juventude como período - é sentida e vivida pela grande maioria dos jovens, que não são aceitos em suas identidades intensamente insurgentes, mas sim como mera fase de complementação da formação produtiva para se chegar ao ápice da razão humana produtiva - nesta sociedade em que se vive para trabalhar, trabalha para comer, e quando dá e o que dá; acreditando eternamente numa vida melhor e trabalhando para isso - é o que põe a modernidade em curso! 
A relação reflexiva se completa com o desejante e impossível (ao menos biológica e morfologicamente) regresso do adulto à vida juvenil e suas características de intensidade em potencialidades e o eterno processo de lamentação de que desta condição decorre. O que resulta nas suas dinâmicas de dominação do outro, do diferente que acaba sendo uma ameaça ao ethos burguês médio, ao $e u$ adulto por demais permeado e dominado pela dinâmica atordoante da vida de produtor/consumidor e sua cartilha rígida de procedimentalidades e identidades permitidas e ordinárias.

Assim que se entende a juventude como uma categoria (composta por um grupo de indivíduos viventes e desejantes por reconhecimento) que foi criada por e integrada à modernidade, mas desde a gênese da categoria, a partir de uma intencionalidade meramente utilitarista, são entendidos como indivíduos que estariam sendo formados a conformar a sociedade do futuro (que é cada vez mais presente e mais inalcançável) - a expandir e aprimorar as capacidades produtivas e consumidoras -; sem verdadeiramente reconhecer os indivíduos que a compõem como entidades portadoras de sentimentos e identidades autônomas e dignas do poder de fala, de ser e querer; mas meramente objetos da intervenção da adulteridade imposta pelo paradigma de sociabilidade liberal/ocidental, entendendo esta juventude como um repositório da doutrina pertinente ao ethos burguês.

Essa situação é aquela em que se encontram as infâncias e juventudes, num processo antigo de desempoderamento do saber rival, podendo ser analisado a partir da proposta de Zygmunt Bauman, que elucida os esforços tutelares, educadores, punitivos - únicas facetas do Estado jardineiro que as juventudes conhecem e têm contato, sempre na posição de objeto de intervenção, sem vez e voz:

Em vez de deduzir sua autoconfiança da crença no progresso, a elite educada forjou a idéia de progresso a partir da imaculada experiência de sua superioridade. Em vez de retirar seu zelo missionário proseli- 
tista de uma crença acrítica na infinita perfectibilidade do homem, ela cunhou a idéia da maleabilidade da natureza humana, a capacidade de ser moldada e melhorada pela sociedade a partir de seu próprio papel disciplinar, instrutivo, educador, tutelar, punitivo e reformador, tendo em mira outras categorias que não ela própria. A experiência de uma categoria constituída no papel de jardineiro em relação a todas as demais categorias foi reconstruída como uma teoria da história. Como se seguisse o preceito metodológico de Marx de examinar a anatomia do homem como chave para a anatomia do macaco, a elite educada usou seu próprio modo de vida, ou o modo de vida daquela parte do mundo que ela presidia (ou pensava presidir), como referência para medir e classificar outras formas de vida - passadas e presentes - como atrasadas, subdesenvolvidas, imaturas, incompletas, deformadas, mutiladas, distorcidas e outros estágios ou versões inferiores de si mesma (Bauman, 2010, p. 156).

É dessa forma que Zygmunt Bauman (2010) analisa a pretensa autoincumbida tarefa, por parte dos intelectuais, de guia da sociedade e seu processo evolutivo a um suposto paradigma de sociabilidade melhor e edificante.

Nesta mesma linha, atribui-se a contemporaneidade da gestão, controle e pretensão de emancipação da juventude. Imbuídos de boas intenções (quer-se acreditar nisto), mas inabaláveis crédulos da incapacidade da autogestão ou mesmo participação (e voz) dos próprios envolvidos, tornados meros objetos do saber dos intelectuais filantropos e empresários com sua pseudorresponsabilidade social.

É nessa medida que se entende o período atual em que se encontram as juventudes - propalado como de direitos e humanitário -, tributário de uma dinâmica e gestão totalitária de significações impostas e inquestionadas.

Assim, propõe-se este esforço teórico-prático, de ressignificar os papéis sociais, empoderar os indivíduos diretamente envolvidos com a trama pública (de interesses privados) e desmistificar os papéis do Estado 
diante de tal problemática. Assim, resgatar o papel dos indivíduos, e em especial para o presente trabalho - as infâncias e juventudes - e sua produção de saberes comuns e populares, na resolução dos próprios conflitos/ necessidades e assuntos que a eles interessam e sobre eles incidem; a partir de uma matriz teórica e cultural outsider (para o sistema dominante), insurgente e comunitária.

Propugna-se claramente por um processo de refundação e ressignificação da concepção de política e de Direito, demonstrando o quanto este existe para além dos espaços estatais oficiais; que são plurais, ainda que não reconhecidos e até desconhecidos ou ignorados, e o quanto a política está impregnada e embrenhada no Direito (devendo mesmo estar) ao arrepio da falácia e cínica proposta positivista de pseudoneutralidade justificante e legitimante de dominações e perversidades históricas no Direito e da separação entre Direito e política - ambos tornados campos de dominação - quando podem ser de lutas e diálogos/trocas emancipatórias.

Nesta linha, sobre a dimensão participativa e que entrelaça o Direito e a política, propugna-se por uma novíssima retórica como um processo simultâneo de desconstrução-construção de um mundo de materialidades e sentidos, para viabilizar a transição paradigmática calcada em trocas e diálogos intersubjetivos e interculturais envolvendo a juventude outsider/ transgressora.

Assim que se propugna por um Direito plural e dialogal, alternativo e acessível, que permita a participação dos próprios envolvidos e dos mais afetados pelas decisões, que não devem partir de cima para baixo, mas serem construídas de baixo para cima, impregnando e religando a ponte entre o Direito e a política, ambos sob a principiologia da igualdade (inclusive na diferença) e da democracia, ou seja, no compartilhamento de saberes e poderes, conformando uma esfera de solidariedade renovada, ressignificada. Nesta linha, assevera Fabiana Marion Spengler (2010, p. 230): 
Assim é necessário recordar que enquanto o totalitarismo erradica o conflito e elimina toda a possibilidade de oposição, a democracia baseia-se no pluralismo de opiniões e na sua oposição conflitual. Por conseguinte, a democracia é o regime que, pela primeira vez na história, não se propõe a eliminar os conflitos, e sim torná-los visíveis, esforçando-se para lhes garantir desfecho negociável com a ajuda de procedimentos aceites. Num regime democrático o conflito é, pois, interminável [...] por aí se vê que a democracia moderna é essencialmente transgressiva, não possuindo base estável.

Uma autêntica esfera de construção da democracia a partir da participação e fortalecimento da cidadania, instituinte da democracia como menciona Vera Regina Pereira de Andrade (2003b), não como instância abstrata (menos que) garantida no plano da legalidade positivista ou como algo obtido e acabado; mas como uma construção diária a serviço da construção de alternativas e resolução de conflitos a partir de uma dinâmica dialogal e participativa, envolvendo os próprios afetados e diretamente interessados, reconhecidos como detentores de saber-poder relevante, identidade e coproduzindo alteridade.

Neste processo (eternamente inacabado - liminar) de (des)pensar o Direito e a política, e (re)ligá-los, para complementar e contribuir com esta interface entre o Direito e a política, na sua relação com a juventude traz-se a contribuição de Enrique Dussel (2009), que direciona a lente analítica para a questão da política e seu potencial transformador e emancipatório a partir da análise do poder e sua legitimidade, bem como complexidades relacionais e institucionais.

É nesse sentido que guarda importância o resgate do poder dos indivíduos envolvidos com a esfera público-estatal punitivo weberiana, como elementar resgate da ideia de poder legítimo como base na ideia de público (numa acepção dusseliana e que remonta à democracia aristotélica moderna calcada na igualdade e diálogo intercultural e intergeracional). Na acepção fornecida por Dussel (2009, p. 54) da potentia: 
El poder-poner en la existencia a los entre políticos es el tener poder (potentia); es decir, el poder es el poder-poner los entes políticos: la potestas. El poder ejercer el poder se origina en el querer en el que consiste la voluntad; es decir, sin voluntad no hay poder, ya que la voluntad es la fuerza, la potentia, el motor, la condición del poder. Ser-voluntad es el querer por sí de la vida humana en su permanecer y aumentar. El querer de la voluntad asegura a la vida humana en su sobre-vivir en la duración del tiempo. Si la vida pierde el querer vivir queda a la deriva, se encuentra en situación de suicidio. Las mediaciones que constituyen el nivel óntico de la política, o la totalidad de los entes políticos en tanto políticos, quedan así fundados ontológicamente en la Voluntad de Poder, en el Poder de la Voluntad - es una primera instancia abstracta y general.

Esta potentia que surge do sentimento de exclusão e a consequente rebeldia - tornada alteridade insurgente - dos indivíduos que somente têm sido vítimas das dinâmicas sistêmicas do aparato punitivo e reprodutor de sentidos na modernidade burguesa; nas palavras de Dussel (2009, p. 65):

De lo que se trata para nosotros es de construir cada categoría por referencia a su fundamento ontológico; es decir, fundarlas con coherencia lógica, para relanzar deconstructivamente dicha critica de todo el sistema de categorías desde la exterioridad de los oprimidos o excluidos. Esto nos llevaría a exponer el concepto de hiper-potentia de una comunidad de oprimidos o excluidos del orden político vigente, que lucharían para su transformación (la nueva potestas futura).

Em sequência, a contribuição de Emmanuel Levinas permite e ajuda a começar a pensar nos indivíduos como sujeitos que subjazem e vão além dos conceitos e símbolos aos quais geram, dão sentido e pertencem; e (des)pensar o complexo paradigma de sociabilidade autoritária humanistaocidental. Assim escreve Levinas: 
Salvo para outrem. Nossa relação com ele consiste certamente em querer compreendê-lo, mas esta relação excede a compreensão. Não só porque o conhecimento de outrem exige, além da curiosidade, também a simpatia ou amor, maneiras de ser distintas da contemplação impassível. Mas também porque na nossa relação com outrem, este não nos afeta a partir de um conceito. Ele é ente e conta como tal. Reportar-se ao ente enquanto ente significa, para Heidegger, deixar-se o ente, compreendê-lo como independente da percepção que o descobre e apreende. É por esta compreensão precisamente que ele se dá como ente e não somente como objeto (Levinas, 1997, p. 26-27).

Em relação às juventudes, o processo de conceituação ocasiona o encerramento e castração dos indivíduos/sujeitos a que se refere e que pretende conceituar e compreender. Ainda que permeado de boas intenções projetando práticas sociais (como políticas ou leis) é dinamizado a partir de uma lógica totalitária, no momento em que se entende como detentor do saber apto a moldar a vida e dar (impor) sentido à existência destes sujeitos que se propõe a compreender (docilizar).

Assim, Emmanuel Levinas (1997) entende que esse processo de compreensão produzida na dinâmica moderna a partir dessa prática autoritária, definitória e classificatória é uma dinâmica de negação do indivíduo enquanto dotado de vontades, saberes identidades. Assim apresenta Dussel:

aunque los principios éticos son subsumidos como políticos en el campo político, queda un ámbito trascendental de lo ético en la política, no ya como principios abstractos normativos, sino como la carnalidad real y concreta de cada sujeto que cumple alguna función en dicho campo. Cada sujeto, en su corporalidad vulnerable, sigue siendo siempre de alguna manera trascendental al campo político, como la alteridad que grita cuando no se cumplen sus exigencias. Es la exterioridad de la subjetividad viviente corporal con respecto a toda acción o institución política, como la Diferencia, como la Dignidad del Otro ciudadano como otro, como otro que uno mismo, como otro que la comunidad política como totalidad. Esa trascendentalidad del sujeto humano a todo campo 
y a través de todo campo, también del campo y los sistemas políticos, nos recuerda que nunca se pueden cumplir todas las expectativas de todos los miembros de la comunidad política. La finitud de la contingencia de la acción y las instituciones nos deben recordar que el dolor y el grito del sujeto es un más allá de infinita exigencia y normatividad política (Dussel, 2009, p. 395).

$\mathrm{O}$ ato de incluir, na generalidade que se impõe à humanidade, com o que se produz “[a] morte [do indivíduo], o ser vivente entra na totalidade, porém não pensa mais nada. Pensante, o ser que se situa na totalidade não é absorvido nela. Ele existe em relação a uma totalidade, mas permanece aqui, separado da totalidade, eu” (Levinas, 1997, p. 37), não se produz a aceitação do indivíduo como ente em si mesmo, nem mesmo permite a sua emancipação, como sujeito apto a participar da modificação de outrem(ns), senão apenas na posição de indivíduos que devem ser modificados, conhecidos, estudados - como objetos.

Para Levinas, o indivíduo é um ente em si mesmo, e é incapaz de ser apreendido pelo saber de outro indivíduo em sua totalidade, multiplicidade e complexidade. Nesta linha, escreve:

A compreensão, ao se reportar ao ente na abertura do ser, confere-lhe significação a partir do ser. Neste sentido, ela não o invoca, apenas o nomeia. E, assim, comete a seu respeito uma violência e uma negação. Negação parcial é violência. E esta parcialidade descreve-se no fato de que o ente, sem desaparecer, se encontra em seu poder. A negação depende de mim. A posse é o modo pelo qual um ente, embora existindo, é parcialmente negado. Não se trata apenas do fato de o ente ser instrumento e utensílio - quer dizer meio; ele é também fim consumível, é alimento e, no gozo, se oferece, se dá, depende de mim (Levinas, 1997, p. 31).

A partir deste processo de reconhecimento do indivíduo, a partir de sua identidade, de seus saberes, experiências, como Emmanuel Levinas (1997) propõe, em sua entidade, em sua singularidade, multiplicidade e 
complexidade. Assim se poderia pensar em ressignificar a política como instância de diálogo, de tomadas de decisão, como espaço de aceitação do outro e de todos, como iguais em suas diferenças e como indivíduos tornados sujeitos livres.

Também o resgate legítimo da proximidade da política com a justiça, rompendo com a pseudoneutralidade tecnicista weberiana que permeia os procedimentos judiciais na modernidade e uma justiça de pequena escala, ${ }^{19}$ mas que se pretende pretensamente como universal (apreendendo e produzindo sentidos gerais e abstratos).

Neste sentido, as juventudes como categoria, ainda que desorganizada, podem contribuir com as suas entidades identitárias, com seus saberes e sofrimentos historicamente silenciados, com as suas vidas de subalternidade como elemento congregador, permitindo a estes indivíduos retornarem a si e tomarem consciência de sua própria condição (de subalternidade e dominação) a irromperem no real pela rebeldia, como propunha Alain Touraine (2007), transformando-se em categoria, não meramente analítica, mas também de atuação, de contestação, projetando fazer parte ativa na modernidade como protagonista de suas próprias histórias, não apenas na condição de objeto da história e projeção das expectativas adultocêntricas. Desta forma propõe Levinas:

O pensamento começa, precisamente, quando a consciência se torna consciência de sua particularidade, ou seja, quando concebe a exterioridade para além de sua natureza de vivente, que o mantém; quando ela se torna consciência de si ao mesmo tempo que consciência da exterioridade que ultrapassa sua natureza, quando ela se torna metafísica. $\mathrm{O}$ pensamento estabelece uma relação com uma exterioridade não assumida. Como pensante, o homem é aquele para quem o mundo exterior existe. Em consequiência, sua vida dita biológica, sua vida estritamente interior, se ilumina de pensamento (1997, p. 36).

${ }^{19}$ Em plano de detalhamento, como referido por Santos (2000) na Cartografia do Direito. 
Esta dinâmica de tomada de consciência diante da própria subalternidade, bem como a capacidade e potencialidade do conhecimento que se produz a partir desta dinâmica inter-relacional e intergeracional (tendo em vista que a grande guerra epistemológica é travada entre gerações), leva ao que Dussel (2009) chama de potentia existente em todo e qualquer indivíduo por si só, em sua vontade de viver (e aí se inclui a vontade/ necessidade de fazer parte e ser reconhecido) transformada em potestas legítima, quando a categoria fragmentada e desorganizada ganha corpo e toma forma simbólica e discursiva, transformando-se em multidimensionalidade humana, de contato, de relações, de saberes e sofrimentos compartilhados e interiorizados, tornando-se política.

Assim um novíssimo paradigma de sociabilidade passa, em grande medida, por processos complexos e abrangentes de modificação e de reafirmação cultural, de tomada de consciência, uma consciência não meramente contemplativa, mas (re)ativa, modificadora, emancipadora.

Emancipação que é tributária da criação e recriação de dinâmicas democráticas a partir de uma perspectiva da democracia construída pelos próprios envolvidos em sua trama diária, e não mais meramente como um projeto de governo, outorgando tal papel aos súditos do Estado, a partir de uma cidadania instituinte na construção partilhada de uma democracia instituída em constante e eterno processo em curso.

\section{CONSIDERAÇÕES FINAIS}

À guisa de considerações finais, ou mesmo aportes conclusivos, reafirma-se o entendimento de que estariam os Conselhos inseridos em uma realidade material e simbólica estruturalmente definida e controlada. Neste sentido, os Conselhos acabam por fazer parte de uma complexa 
trama sistêmica em que se utiliza de estratagemas de pseudopolítica representativa, e sob o controle técnico-jurídico, que se embasa/justifica em uma suposta necessidade de regulação oficial.

É nessa linha que se entende os Conselhos como instituições mais controladas do que controladoras, fiscalizadoras ou mesmo promotoras e produtoras de realidade cidadã e participativa. Tendo em vista que se encontram como pertencentes a esta superestrutura situada em meio a uma crise paradigmática e de degenerescência, que, por assim ser, perde a capacidade de fundamentar ou camuflar esta fundamentação que mantém e perpetua suas instituições materiais e simbólicas; estando imersa em uma dinâmica que vai desde os discursos pseudo-humanistas, passando por uma estrutura conceitual e simbólica vaga e genérica, e culminando em uma prática historicamente ineficiente e legitimadora do status quo de dominação hegemônica. Assim, trata-se de uma problemática mais conceitual e de legitimidade do que de procedimentalidade.

É nessa linha que se preconiza por um processo de revolução paradigmática que diz respeito à ciência, ao Direito e a política como instâncias democráticas e plurais na construção social a partir da participação (e não representação). Assim, fala-se da quebra do monopólio de dizer o Direito e fazer política por parte do Estado, onde se empodera as capacidades de dizer o que fazer e como fazer a partir das relações conflituosas e socialmente problemáticas partindo das próprias pessoas nele envolvidas/ interessadas e afetadas, rompendo-se com o binômio entre poder-saber científico e comum.

Nesse sentido, entende-se como dois elementos centrais e intimamente ligados. Primeiro, o empoderamento dos indivíduos em sua a capacidade simbólica das entidades juvenis como dotados da potencialidade de produzir saber, e tal saber como legítimo, que produz os sentidos para a vida do próprio indivíduo significante, assim como representa a quebra das estratégias dominadoras disfarçadas de educação ou reintegração social. 
E, em segundo, a multidimensionalidade, o inter-relacionamento, o contato permeado pelo diálogo, sendo este um dos grandes nós da problemática da democracia e do paradigma de juridicidade moderna - a incapacidade genética e epistemológica de diálogo -, pois este impõe o reconhecimento do outro como figura dotada de poder.

Com isso, e a partir da multidimensionalidade juvenil subalterna produzir um direito de grande escala, ou uma microgovernança da Justiça a partir de um processo radical de política da alteridade, de democracia e participação social, refundando a cidadania e a sua capacidade de produzir saber e legitimar conhecimentos produzidos na periferia da epistemologia dominante, rompendo com a bondade pública totalitária.

\section{REFERÊNCIAS}

ALVAREZ, Marcos Cesar. Controle social: notas em torno de uma noção polêmica. In: Revista São Paulo em Perspectiva, n. 18, p. 168-176, 2004.

ANDRADE, Vera Regina Pereira. A ilusão da segurança jurídica: do controle da violência à violência do controle penal. Porto Alegre: Livraria do Advogado, 2003a.

Sistema penal máximo x cidadania mínima: códigos da violência na era da globalização. Porto Alegre: Livraria do Advogado, 2003b.

BARATTA, Alessandro. Criminologia crítica e crítica do Direito Penal: introdução à sociologia do direito penal. Rio de Janeiro: Freitas Bastos; Instituto Carioca de Criminologia, 1999.

. La Niñez Cómo Arqueología del Futuro. In: UNICEF. Justicia y Derechos del Niño, n. 9, Santiago, Chile, 2007a. p. 7-15.

. Democracia y Derechos del Niño. In: UNICEF. Justicia y Derechos del Niño, n. 9. Santiago, Chile, 2007b. p.17-25.

BAUMAN, Zygmunt. A sociedade individualizada: vidas contadas e histórias vividas. Rio de Janeiro: Jorge Zahar Editor, 2008a. 
BAUMAN, Zygmunt. Vida para consumo: a transformação das pessoas em mercadoria. Rio de Janeiro; Jorge Zahar Ed., 2008b.

. Vidas desperdiçadas. Rio de Janeiro: Jorge Zahar editor, 2005.

. Modernidade líquida. Rio de Janeiro: Jorge Zahar, 2001.

. Em busca da política. Rio de Janeiro: Jorge Zahar Editor, 2000.

. O mal-estar da pós-modernidade. Rio de Janeiro: Jorge Zahar, 1998.

BERCOVICI, Gilberto. Soberania e constituição: para uma crítica do constitucionalismo. São Paulo: Quartier Latin, 2008.

CALVI, Kéttini Upp. O controle social nos conselhos de políticas e de direito. Revista Emancipação, UEPG, n. 8, p. 9-20, 2008.

COSTA, Lucia Cortes. A estrutura da vida cotidiana: uma abordagem através do pensamento lukacsiano. In: Revista Emancipação, UEPG, vol. 1, n. 1, p. 37-57, 2001.

COSTA, Lucia Cortes. Uma discussão humanitária da globalização. In: Revista Pesquisa e Debate, PUC/SP, vol. 10, n. 1, p. 30-54, 1999.

DUSSEL, Enrique. Política de la liberación vol. II: arquitectónica. Madrid, España: Editorial Trotta, 2009.

DUSSEL, Enrique. Materiales para una política de la liberación. Madrid: Plaza Valdez Editores, 2007.

DUSSEL, Enrique. 20 tesis de política. Buenos Aires; São Paulo: CLACSO; Expressão Popular, 2006.

FERREIRA, Ivanete Boschetti. Assistência social: os limites à efetivação do direito. In: Revista Katalysis, n. 4, 1999.

GOHN, Maria da Gloria. Empoderamento e participação da comunidade em políticas sociais. In: Revista Saúde e Sociedade, vol. 13, p. 20-31, 2004.

HARDT, Michael; NEGRI, Antônio. Multidão: guerra e democracia na era do Império. Rio de Janeiro: Record, 2005.

HARDT, Michael; NEGRI, Antônio. Império. Rio de Janeiro; São Paulo: Editora Record, 2006. 
LEAL, Jackson da Silva. Vulnerabilidades e sobrecargas de punição no direito penal do menor. In: Revista Intratextos, Rio de Janeiro, v. 3, n. 1, p. 143-166, 2011.

LEVINAS. Emmanuel. Entre nós: ensaios sobre a alteridade. Tradução Pergentino Stefano Pivatto et al. Petrópolis, RJ: Vozes, 1997.

LUHMANN, Niklas. Introdução à teoria dos sistemas. Tradução Ana Cristina Arantes Nasser. Petrópolis, RJ: Vozes, 2010.

MÉSZÁROS, István. Para além do capital. Tradução Paulo Cezar Castanheira. São Paulo: Boitempo, 2011.

NOGUEIRA, Marco Aurélio. Gestão participativa, Estado e democracia. In: um estado para a sociedade civil: temas éticos e políticos da gestão democrática. São Paulo: Cortez, 2004.

PEREIRA, Potyara A. P. Política social: temas e questões. São Paulo: Editora Cortez, 2009.

POCHMANN, Marcio. Proteção social na periferia do capitalismo: considerações sobre o Brasil. In: Revista São Paulo em Perspectiva, n. 18, p. 3-18, 2004. ROSA, Alexandre Morais. Introdução crítica ao ato infracional: princípios e garantias constitucionais. Rio de Janeiro: Lumen Juris, 2007.

SANTOS, Boaventura de Sousa. A crítica da razão indolente: contra o desperdício da experiência. São Paulo: Cortez, 2000.

SANTOS, Boaventura de Sousa. Gramática do tempo: para uma nova cultura política. São Paulo: Cortez, 2006.

SANTOS, Boaventura de Sousa Santos. Introdução a uma ciência pós-moderna. Rio de Janeiro: Graal, 1989.

SANTOS, Boaventura de Sousa. Um discurso sobre as ciências. Porto: Edições Afrontamento, 1987.

SANTOS, Boaventura de Sousa. Sociología jurídica crítica: para un nuevo sentido común en el Derecho. Madrid, España; Bogotá, Colombia: Editorial Trotta; Ilsa, 2009. 
SOUZA, Jessé. A construção social da subcidadania: para uma sociologia política da modernidade periférica. Belo Horizonte; Rio de Janeiro: UFMG; Iuperj, 2003.

SPENGLER, Fabiana Marion. Da jurisdição à mediação: por uma outra cultura do tratamento de conflitos. Ijuí, RS: Ed. Unijuí, 2010.

TOURAINE, Alain; KHOSROKHAVAR, Farhad. A busca de si: diálogo sobre o sujeito. Tradução Caio Meira. Rio de Janeiro: Bertrand Brasil; Difel, 2004. TOURAINE, Alain. Um novo paradigma: para compreender o mundo de hoje. Petrópolis, RJ: Vozes, 2007.

TOURAINE, Alain. Pensar outramente: o discurso interpretativo dominante. Petrópolis, RS: Vozes, 2009.

VIANNA, Maria Lucia Werneck. A nova política social no Brasil: uma prática acima de qualquer suspeita teórica? In: Revista Praia Vermelha, ESS/UFRJ, vol. 18, n. 1, 2008.

WOLKMER, Antônio Carlos. Pluralismo jurídico: fundamentos de uma nova cultura do Direito. São Paulo: Editora Alfa Ômega, 1997.

Recebido em: 29/6/2012

Aprovado em: 5/9/2012 